\author{
Military Technical College \\ Kobry El-Kobbah, \\ Cairo, Egypt
}

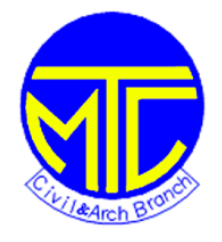

\author{
$10^{\text {th }}$ International Conference \\ on Civil and Architecture \\ Engineering \\ ICCAE-10-2014
}

\title{
Mineral Admixtures : The Key To High Strength Concrete
}

\section{By}

Yousry B I Shaheen*, Nabil Amer** , Essam El Tehawi** , Mohamed Omar**

\section{Abstract:}

This paper presents the results of an experimental investigation for the reuse of some locally available industrial waste materials namely, granulated blast-furnace slag (BFS), pulverized fuel ash (PFA), limonite, and silica fume (SF) in producing high strength concrete. Developing of high strength concretes has a worth priority field of study worldwide, their production is largely expanded in the last two decades. Potential applications of high strength concrete are in producing thin durable sections and in strengthening and repairing defaulted structures.

The principal engineering properties of the developed concretes such as compressive strength, modulus of rupture, and modulus of elasticity were investigated. .The test results revealed that the resulting concretes have excellent strength properties superior to those made of only ordinary Portland cement. The suggested utilization of these industrial waste materials provides a useful mean of disposal for a considerable amount of these solid wastes and contributes in the environmental protection.

Keywords: Environmental Protection; Industrial Waste; Blast-Furnace Slag; Pulverized Fuel Ash; Silica Fume.

* Menofia university

**Egyptian Armed Forces 


\section{INTRODUCTION}

Industrial waste materials posse hydraulic properties and can be used as admixtures or partial replacements to Portland cement owing to their chemical composition and to their structure, which is a consequence of their formation process. The most frequent and important of such materials are blast-furnace slag, fly ash from pulverized coal burning in power plants, and silica fume; but some other types of slag, ashes, and other natural and artificial pozzolans are also used.

The practice of grinding blast-furnace slag (BFS), a by product from the iron ore industry, and Portland cement separately, and combining them at the mixer, has been widely accepted because of the practical advantages of matching the cement and slag to optimize the properties of the composite cement, and of adjusting their proportions to suit the needs of a particular situation. In 1990, Swamy and Bouikini suggested a simple method to obtain concrete of strength $50 \mathrm{MPa}$ at 28-days age having slag replacement ratios of $50 \%$ and $65 \%$ by weight of cement. The test results showed that slag concrete mixtures achieved almost the same compressive strengths as ordinary Portland cement concretes. However, when exposed to dry environment, slag replacement ratios beyond $50 \%$ showed some retrogression of strength.

Silica fume, a by-product from the manufacture of silicon and ferro-silicon alloys, is a mineral composed of ultra fine amorphous glassy spheres of silicon dioxide $\left(\mathrm{SiO}_{2}\right)$. The manufacture process involves the reduction of high purity quartz in electric-arc furnace heated to $2000^{\circ} \mathrm{C}$. The micro silica originates from the condensation of $\mathrm{SiO}_{2}$ vapor, which mixes with oxygen in the upper collar part of the furnace. In 1994, Ozyildirim studied the idea of using small amounts of silica fume (SF) with Slag to produce low permeable concrete needed for transportation structures. Various combinations of silica fume and slag were evaluated for strength and permeability. It was determined that $3 \%$ to $5 \%$ silica fume with up to $47 \%$ slag at a water/binder ratio of $0.4-0.45$ produces economical concretes with very low permeability and adequate strength.

Concrete containing pulverized fuel ash (PFA), a solid waste material extracted by electrical or mechanical means from the flue gases of the power stations boilers fired with pulverized coal have been used for a long time in mass concrete construction but their use in structural applications is limited. In 1991, Y.B.I Shaheen investigated the effectiveness of utilizing PFA as a partial replacement to ordinary Portland cement with replacement levels up to $50 \%$. PFA showed a beneficial effect on the strength gain at later ages than Portland cement as a result of the retard pozzolanic action of PFA which ensured long term strength development. 
This paper presents a comprehensive study conducted to find out the possibility of using the locally available industrial waste materials in producing high strength concrete mortars required for many applications such as low cost housing, repair works, and ferrocement construction. The study included three main waste materials namely; blastfurnace slag (BFS), pulverized fuel ash (PFA), and silica fume (SF). Strength characteristics of mortar mixtures with different replacement levels are reported including compressive strength, modulus of rupture, and modulus of elasticity.

\section{CHEMICAL COMPOSITION}

The chemical composition and physical properties of the cement used is shown in Table (1) while the chemical composition and physical properties of the three industrial waste materials under investigation are presented in Tables (2), (3), and (4). The values obtained by chemical analysis are expressed in terms of percentages. It is interested to note that the chemical composition of BFS, PFA, and SF is very similar to that of Portland cement. The major difference is the relative quantity of each compound. Portland cement is very rich in lime (CaO) compared to PFA and SF; while BFS has as $50 \%$ lime as Portland cement. However, BFS has high content of magnesium oxide (MgO) than both PFA and SF. The highest silica content was found in SF followed by PFA, while BFS had the least. It is well known that the hydration activity increases with the increase in the silica content, while it decreases with the increase in the Magnesium oxide content. During hydration of Portland cement, free lime is released forming the necessary ingredient for the reaction with the used pozzolanic materials forming strong and durable compounds.

Table 1: Chemical Composition of the used Portland Cement.

\begin{tabular}{lrlc}
\hline Chemical Analysis & Weight, $\%$ & Physical Property & Value \\
\hline Silicon dioxide $\left(\mathrm{SiO}_{2}\right)$ & 19.92 & Fineness, $\mathrm{cm}^{2} / \mathrm{gm}$ & 4259 \\
Aluminum oxide $\left(\mathrm{Al}_{2} \mathrm{O}_{3}\right)$ & 5.60 & Compressive strength, MPa & \\
Ferric oxide $\left(\mathrm{Fe}_{2} \mathrm{O}_{3}\right)$ & 3.12 & 3 days & 32.7 \\
Calcium oxide $(\mathrm{CaO})$ & 63.97 & 7 days & 41.2 \\
Magnesium oxide $(\mathrm{MgO})$ & 2.24 & Setting Time, hr: min. & $2: 02$ \\
Sulfur trioxide $\left(\mathrm{SO}_{3}\right)$ & 2.16 & Initial & $2: 30$ \\
Potassium oxide $\left(\mathrm{K}_{2} \mathrm{O}\right)$ & 0.26 & Final & \\
Sodium oxide $\left(\mathrm{NaO}_{2}\right)$ & 0.21 & & \\
Loss in ignition & 2.00 & & \\
Undetermined amount & 0.52 & & \\
Insoluble residue & 1.21 & & \\
Lime saturation factor & 0.97 & & \\
\hline
\end{tabular}


Table 2: Chemical Composition and Physical Properties of Blast-Furnace Slag (BFS).

\begin{tabular}{lrll}
\hline Chemical Analysis & $\%$ & Physical Property & Value \\
\hline Silicon dioxide $\left(\mathrm{SiO}_{2}\right)$ & 34.05 & Fineness, cm ${ }^{2} / \mathrm{gm}$ & \\
Aluminum oxide $\left(\mathrm{Al}_{2} \mathrm{O}_{3}\right)$ & 13.35 & Type $(\mathrm{S} 4)$ & 4000 \\
Iron $(\mathrm{Fe})$ & 0.83 & Packing Density, ton $/ \mathrm{m}^{3}$ & $1.2-1.4$ \\
Calcium oxide $(\mathrm{CaO})$ & 37.20 & Bulk Density, ton $/ \mathrm{m}^{3}$ & $2.28-2.57$ \\
Magnesium oxide $(\mathrm{MgO})$ & 4.54 & True density, ton $/ \mathrm{m}^{3}$ & $3.0-3.473$ \\
Sulfur (S) & 1.44 & Water Absorption, \% by mass & $1.0-1.8$ \\
Manganese oxide $\left(\mathrm{P}_{2} \mathrm{O}\right)$ & 2.92 & Apparent Porosity, \% & $10.5-14.0$ \\
Sodium oxide $\left(\mathrm{NaO}_{2}\right)$ & 1.45 & Cold crushing Strength, MPa & $20.7-36.7$ \\
Barium oxide $(\mathrm{BaO})$ & 3.95 & & \\
Potassium oxide $\left(\mathrm{K}_{2} \mathrm{O}\right)$ & 0.27 & & \\
& & & \\
\hline
\end{tabular}

Table 3: Chemical Composition and Physical Properties of Pulverized Fuel Ash (PFA).

\begin{tabular}{lrlc}
\hline Chemical Analysis & Weight, $\%$ & Physical Property & Value \\
\hline Silicon dioxide $\left(\mathrm{SiO}_{2}\right)$ & 51.87 & Fineness, $\mathrm{cm}^{2} / \mathrm{gm}$ & 3700 \\
Aluminum oxide $\left(\mathrm{Al}_{2} \mathrm{O}_{3}\right)$ & 26.25 & Specific gravity & 2.17 \\
Titanium oxide $\left(\mathrm{TiO}_{2}\right)$ & 0.99 & Density $\left(\mathrm{kg} / \mathrm{m}^{3}\right)$ & 2410 \\
Ferric oxide $\left(\mathrm{Fe}_{2} \mathrm{O}_{3}\right)$ & 9.41 & & \\
Calcium oxide $(\mathrm{CaO})$ & 1.05 & & \\
Magnesium oxide $(\mathrm{MgO})$ & 1.43 & & \\
Sulfur trioxide $\left(\mathrm{SO}_{3}\right)$ & 0.50 & & \\
Potassium oxide $\left(\mathrm{K}_{2} \mathrm{O}\right)$ & 3.76 & & \\
Sodium oxide $\left(\mathrm{NaO}_{2}\right)$ & 0.99 & & \\
Free lime & 0.90 & & \\
Loss in ignition & 2.58 & & \\
Phosphorus Oxide $\left(\mathrm{P}_{2} \mathrm{O}_{5}\right)$ & 0.27 & & \\
\hline
\end{tabular}


Table 4: Chemical Composition and Physical Properties of Silica Fume (SF).

\begin{tabular}{lrll}
\hline Chemical Analysis & \multicolumn{1}{c}{$\%$} & Physical Property & Value \\
\hline Silicon dioxide $\left(\mathrm{SiO}_{2}\right)$ & 97.10 & Fineness, $\mathrm{cm}^{2} / \mathrm{gm}$ & 167000 \\
Aluminum oxide $\left(\mathrm{Al}_{2} \mathrm{O}_{3}\right)$ & 0.30 & particle size $>0.045 \mathrm{~mm}, \%$ & 0.25 \\
Ferric oxide $\left(\mathrm{Fe}_{2} \mathrm{O}_{3}\right)$ & 0.50 & Bulk Density & \\
Calcium oxide $(\mathrm{CaO})$ & 0.20 & (undensified), ton $/ \mathrm{m} 3$ & \\
Magnesium oxide $(\mathrm{MgO})$ & 0.50 & & \\
Sulfur dioxide $\left(\mathrm{SO}_{2}\right)$ & 0.15 & & \\
Sodium oxide $\left(\mathrm{Na}_{2} \mathrm{O}\right)$ & 0.20 & & \\
Potassium oxide $\left(\mathrm{K}_{2} \mathrm{O}\right)$ & 0.50 & & \\
Water $\left(\mathrm{H}_{2} \mathrm{O}\right)$ & 0.55 & & \\
PH fresh & 6.00 & & \\
\hline
\end{tabular}

\section{EXPERIMENTAL PROGRAM}

The primary objective of this study was introducing environmentally clean method for utilizing the locally available industrial waste materials through investigating the efficiency of these waste materials (BFS, PFA, and SF) as partial replacements of cement in producing high performance mortar. The efficiency of any pozzolanic material is generally defined in terms of strength characteristics with the control strength as reference. It is accepted that the strength characteristic of the mortar or concrete is used as a reasonable indicator for its durability.

\subsection{Mix Proportioning}

The test program composed of three main series: series A, series B, and series C. In series A, cement was partially replaced by BFS and the replacement levels of slag ranged from $10 \%$ to $40 \%$ by weight of cement in intervals of $10 \%$. For all mixes of series $A$, the water/cementitous material ratio was kept at 0.25 while the sand/cementitous ratio was 1.8 . While in series $B$, cement was partially replaced by PFA where the replacement ratios ranged from $30 \%$ to $70 \%$ by weight of cement in intervals of $10 \%$. For all mixes of series $\mathrm{B}$, the water/cementitous material ratio was kept at 0.3 while the sand/cementitous ratio was 1.8 . SF was used in series $\mathrm{C}$ as a cement replacement with replacement levels ranged from $5 \%$ to $25 \%$ in interval of $5 \%$. The water/cementitous material ratio was kept at 0.35 while the sand/cementitous ratio was 2.0 for all mixes. Throughout the experimental program, the concrete mortar ingredients were batched by mass in a pan mixer according to ASTM C192. The slag, fly ash, and silica fume were added after the Portland cement in the mixing sequence. The workability of the mix was improved by adding super plasticizer agent as $2 \%$ by weight of binder materials. The ingredients were first dry mixed with a rotating type 
mixer then the water containing the used $2 \%$ dosage of super plasticizer was added. The freshly mixed mortar was tested for workability with the conventional slump-cone test. The mix proportions of the control mixes were designed to give the possible highest strength. This mix design was previously determined based on unpublished preliminary research work. Mix proportions and slump results for the three series (A, B, and C) are summarized in Table (5).

Table 5: Details of Mix Proportions and Fresh Mortar Properties.

\begin{tabular}{|c|c|c|c|c|c|c|}
\hline $\begin{array}{c}\text { Series } \\
\text { Designation }\end{array}$ & $\begin{array}{c}\text { Mix } \\
\text { No }\end{array}$ & $\mathrm{C}+\frac{\mathrm{W}}{\mathrm{BES}}$ & $\frac{\mathrm{C}}{\mathrm{BES}}$ & $\frac{\mathrm{S}}{\mathrm{C}+\mathrm{BES}}$ & $\frac{S P}{C+B E S}$ & $\begin{array}{l}\text { Slump } \\
\text { (mm) }\end{array}$ \\
\hline A & $\begin{array}{l}\text { Ac } \\
\text { A1 } \\
\text { A2 } \\
\text { A3 } \\
\text { A4 }\end{array}$ & $\begin{array}{l}0.25 \\
0.25 \\
0.25 \\
0.25 \\
0.25 \\
\end{array}$ & $\begin{array}{l}100 / 0 \\
90 / 10 \\
80 / 20 \\
70 / 30 \\
60 / 40 \\
\end{array}$ & $\begin{array}{l}1.8 \\
1.8 \\
1.8 \\
1.8 \\
1.8 \\
\end{array}$ & $\begin{array}{l}2 \% \\
2 \% \\
2 \% \\
2 \% \\
2 \% \\
\end{array}$ & $\begin{array}{r}16 \\
10 \\
7 \\
5 \\
3 \\
\end{array}$ \\
\hline $\begin{array}{c}\text { Series } \\
\text { Designation }\end{array}$ & $\begin{array}{l}\text { Mix } \\
\text { No }\end{array}$ & $\frac{\mathrm{W}}{\mathrm{C}+\mathrm{PFA}}$ & $\frac{\mathrm{C}}{\mathrm{PFA}}$ & $\frac{\mathrm{S}}{\mathrm{C}+\mathrm{PFA}}$ & $\frac{\mathrm{SP}}{\mathrm{C}+\mathrm{PFA}}$ & $\begin{array}{l}\text { Slump } \\
(\mathrm{mm})\end{array}$ \\
\hline B & $\begin{array}{l}\text { Bc } \\
\text { B1 } \\
\text { B2 } \\
\text { B3 } \\
\text { B4 } \\
\text { B5 } \\
\end{array}$ & $\begin{array}{l}0.30 \\
0.30 \\
0.30 \\
0.30 \\
0.30 \\
0.30 \\
\end{array}$ & $\begin{array}{l}100 / 0 \\
70 / 30 \\
60 / 40 \\
50 / 50 \\
40 / 60 \\
30 / 70 \\
\end{array}$ & $\begin{array}{l}1.8 \\
1.8 \\
1.8 \\
1.8 \\
1.8 \\
1.8 \\
\end{array}$ & $\begin{array}{l}2 \% \\
2 \% \\
2 \% \\
2 \% \\
2 \% \\
2 \% \\
\end{array}$ & $\begin{array}{r}5 \\
20 \\
90 \\
120 \\
130 \\
140 \\
\end{array}$ \\
\hline $\begin{array}{c}\text { Series } \\
\text { Designation }\end{array}$ & $\begin{array}{c}\text { Mix } \\
\text { No }\end{array}$ & $\frac{\mathrm{W}}{\mathrm{C}+\mathrm{SF}}$ & $\frac{\mathrm{C}}{\mathrm{SF}}$ & $\frac{S}{C+S E}$ & $\frac{\mathrm{SP}}{\mathrm{C}+\mathrm{SF}}$ & $\begin{array}{l}\text { Slump } \\
\text { (mm) }\end{array}$ \\
\hline C & $\begin{array}{l}\mathrm{Cc} \\
\mathrm{C} 1 \\
\mathrm{C} 2 \\
\mathrm{C} 3 \\
\mathrm{C} 4 \\
\mathrm{C} 5\end{array}$ & $\begin{array}{l}0.35 \\
0.35 \\
0.35 \\
0.35 \\
0.35 \\
0.35\end{array}$ & $\begin{array}{c}100 / 0 \\
95 / 5 \\
90 / 10 \\
85 / 15 \\
80 / 20 \\
75 / 25\end{array}$ & $\begin{array}{l}2.0 \\
2.0 \\
2.0 \\
2.0 \\
2.0 \\
2.0\end{array}$ & $\begin{array}{l}2 \% \\
2 \% \\
2 \% \\
2 \% \\
2 \% \\
2 \%\end{array}$ & $\begin{array}{r}55 \\
49 \\
35 \\
22 \\
12 \\
3\end{array}$ \\
\hline
\end{tabular}

\subsection{Test Details}

All mixes were tested for compressive strength, flexure strength, and modulus of elasticity. For each mix, 18 cubes $71 \mathrm{~mm}$ were cast to monitor the compressive strength development up to 6 months; in the present study, compressive strengths up to only 3 months are reported. The flexure strength at 28-days age was determined using 3 plates $25 X 100 X 500 \mathrm{~mm}$. The static modulus of elasticity was measured using 3 prisms 100x100x300mm. Strains at 28-days age were measured by means of a mechanical strain gauge of high sensitivity and two sets of demec points according to BS. 1881: part 1-5 BSI, London, 1983. All cubes, and prisms were cast in two layers in steel molds, 
each layer was compacted using a vibrating table. After casting, all specimens were covered with wet plastic sheets and left in the casting room for 24 hours. The specimens were then demolded and transferred to the moist-curing room until required for testing.

\section{RESULTS AND DISCUSSION}

The test results given in Tables(6), (7), and (8) show the effect of using BFS, PFA, and SF as cement replacements on the mortar mechanical properties. Figure (1) emphasizes a comparison between the effects of the different waste materials on the mortar compressive strength. The effect of these materials on the flexure strength and modulus of elasticity is illustrated in Figures (2) and (3), respectively.

From the results of the compressive strength test, it was found that all replacement levels of BFS resulted in higher compressive strength than that of the control mix at all ages. This improvement in compressive strength may be attributed to the lower hydration heat and refined pore structure. However, a reduction in the rate of the early age strength development was noted. Also it was noted that the hydration of BFS requires longer curing periods since BFS mortars reached their ultimate strength at ages beyond the 28-days age. All BFS replacement levels showed higher flexure strength than the control mix. The optimum replacement percentage was found to be $20 \%$ since the gain in flexure strength decreased at replacement levels higher than 20\%. Using BFS as a cement replacement significantly contributed to the flexure strength. This could be attributed to the lower heat of hydration resulting from BFS than that resulting from ordinary Portland cement. As a result, the number and spread of micro cracks were minimized and consequently higher flexure strengths were achieved. The results of the modulus of elasticity showed that all BFS replacement levels resulted in higher elasticity than the control mix in a trend similar to that of the compressive strength. However, the gain in the static modulus was much lower than that in the compressive strength.

Table 6: The Effect of BFS as Cement Replacement on Hardened Mortar Properties.

\begin{tabular}{|c|c|c|c|c|c|c|c|c|c|}
\hline \multirow{2}{*}{$\begin{array}{l}\text { Mix } \\
\text { No }\end{array}$} & \multicolumn{7}{|c|}{ Compressive Strength, (Mpa) } & \multirow{2}{*}{$\begin{array}{c}\text { Flexure } \\
\text { Strength } \\
\text { (Mpa) }\end{array}$} & \multirow{2}{*}{$\begin{array}{l}\text { Young's } \\
\text { Modulus } \\
\text { (Gpa) }\end{array}$} \\
\hline & $3-d$ & $7-d$ & $14-d$ & 28-d & $90-d$ & $180-d$ & 365-d & & \\
\hline Ac & 46 & 48 & 49.5 & 51 & 55.0 & 60.1 & 61.8 & 4.3 & 29.7 \\
\hline A1 & 48 & 50 & 51.0 & 52 & 56.5 & 67.0 & 79.5 & 6.4 & 30.0 \\
\hline A2 & 47 & 51 & 53.2 & 54 & 58.1 & 70.6 & 85.8 & 6.6 & 30.5 \\
\hline A3 & 39 & 50 & 53.4 & 56 & 64.8 & 76.1 & 89.4 & 5.3 & 31.0 \\
\hline A4 & 35 & 48 & 53.1 & 56 & 71.0 & 83.2 & 97.5 & 4.7 & 31.0 \\
\hline
\end{tabular}


Proceedings of the 10 $^{\text {th }}$ ICCAE-10 Conference, 27-29 May, 2014

\begin{tabular}{|l|l|}
\hline$M Q C$ & 3
\end{tabular}

Table 7: The Effect of PFA as Cement Replacement on The Hardened Mortar Properties.

\begin{tabular}{|c|c|c|c|c|c|c|c|c|c|}
\hline \multirow{2}{*}{$\begin{array}{l}\text { Mix } \\
\text { No }\end{array}$} & \multicolumn{7}{|c|}{ Compressive Strength, (Mpa) } & \multirow{2}{*}{$\begin{array}{c}\text { Flexure } \\
\text { Strength } \\
\text { (MPa) }\end{array}$} & \multirow{2}{*}{$\begin{array}{l}\text { Young's } \\
\text { Modulus } \\
\text { (GPa) }\end{array}$} \\
\hline & $3-d$ & $7-d$ & $14-d$ & $28-d$ & $90-d$ & $180-d$ & $365-d$ & & \\
\hline $\mathrm{Bc}$ & 45.0 & 59.5 & 64.5 & 69.5 & 73.2 & 77.5 & 79.7 & 6.90 & 30.8 \\
\hline B1 & 36.3 & 42.9 & 52.0 & 62.0 & 78.1 & 90.0 & 104.0 & 8.65 & 32.2 \\
\hline B2 & 30.8 & 36.3 & 48.5 & 57.0 & 71.3 & 89.0 & 111.1 & 7.90 & 31.0 \\
\hline B3 & 22.0 & 31.2 & 48.5 & 64.7 & 88.8 & 91.5 & 94.3 & 9.00 & 32.9 \\
\hline B4 & 19.8 & 27.8 & 37.5 & 44.0 & 65.5 & 72.0 & 79.2 & 6.20 & 27.5 \\
\hline B5 & 14.5 & 20.3 & 28.0 & 35.0 & 50.5 & 57.5 & 65.5 & 5.00 & 25.0 \\
\hline
\end{tabular}

From Table (3), it is clear that the substitution of cement by PFA resulted in lower early age strengths. This reduction was proportional to the amount of PFA being introduced into the mix. However, it is interesting to find that the 28-days age compressive strength of the control mix is approximately equal to that of the mix with $50 \%$ replacement with PFA. It was also found that mortars having PFA up to 50\% replacement levels showed slightly higher modulus of elasticity than the control mix. The modulus of elasticity was calculated as the linear portion of the stress-strain curves. The percentage of strength gain at 3 months compared to the 28-days age for high replacement levels was found to be greater than that for low replacement levels. The results of the flexure strength showed significant increase in the strength with an almost typical behavior to that of the compressive strength. The high late age strength of fly ash mortar may be attributed to the reaction of the insoluble fly ash with the lime released by Portland cement during hydration, forming a new strong soluble-hydrate phase.

The compressive strength was found to increase with the increase in the of SF percentage up to $15 \%$, subsequently it decreases. At 3-months age, the compressive strength for the $15 \% \mathrm{SF}$ mix was markedly higher than that of the control mix. From Table (4), it is clear that there is a moderate drop in the early strength up to 7 days compared with the control mix. The explanation for this may be that the pozzolanic reaction took relatively longer time to show effect on strength; while, in the same time, the amount of cement was reduced by the replacement percentage of SF. The flexure strength was found to be affected by the replacement level of SF in the same manner as the compressive strength as shown in Table (4). Also it was found that the static modulus of elasticity increased compared to the control mix up to $15 \%$ replacement level; subsequently it decreased. The variation of the static modulus was in a complete agreement with the compressive strength behavior and most probably for the same previously mentioned reasons. 
Table 8: The Effect of SF as Cement Replacement on the Hardened Mortar Properties.

\begin{tabular}{|c|c|c|c|c|c|c|c|c|c|}
\hline \multirow{2}{*}{$\begin{array}{l}\text { Mix } \\
\text { No }\end{array}$} & \multicolumn{7}{|c|}{ Compressive Strength, (MPa) } & \multirow{2}{*}{$\begin{array}{c}\text { Flexure } \\
\text { Strength } \\
\text { (MPa) }\end{array}$} & \multirow{2}{*}{$\begin{array}{c}\text { Young's } \\
\text { Modulus } \\
\text { (GPa) }\end{array}$} \\
\hline & $3-d$ & $7-d$ & 14-d & 28-d & $90-d$ & $180-d$ & 365-d & & \\
\hline $\begin{array}{l}\text { Cc } \\
\text { C1 } \\
\text { C2 } \\
\text { C3 } \\
\text { C4 } \\
\text { C5 } \\
\end{array}$ & $\begin{array}{l}30.3 \\
29.6 \\
28.0 \\
27.4 \\
26.2 \\
24.7 \\
\end{array}$ & $\begin{array}{l}37.4 \\
41.3 \\
43.0 \\
45.7 \\
42.1 \\
39.0\end{array}$ & $\begin{array}{l}45.0 \\
52.0 \\
56.2 \\
59.2 \\
54.0 \\
48.0 \\
\end{array}$ & $\begin{array}{l}50.5 \\
57.8 \\
61.9 \\
64.6 \\
61.0 \\
56.0 \\
\end{array}$ & $\begin{array}{l}58.6 \\
61.2 \\
70.7 \\
87.0 \\
66.8 \\
65.3 \\
\end{array}$ & $\begin{array}{l}61.5 \\
64.5 \\
72.6 \\
90.7 \\
70.9 \\
65.2 \\
\end{array}$ & $\begin{array}{l}63.2 \\
64.8 \\
71.3 \\
92.5 \\
70.1 \\
63.7 \\
\end{array}$ & $\begin{array}{l}5.40 \\
6.00 \\
6.20 \\
5.95 \\
5.40 \\
4.90 \\
\end{array}$ & $\begin{array}{l}26.4 \\
30.5 \\
33.3 \\
35.0 \\
32.6 \\
28.0 \\
\end{array}$ \\
\hline
\end{tabular}

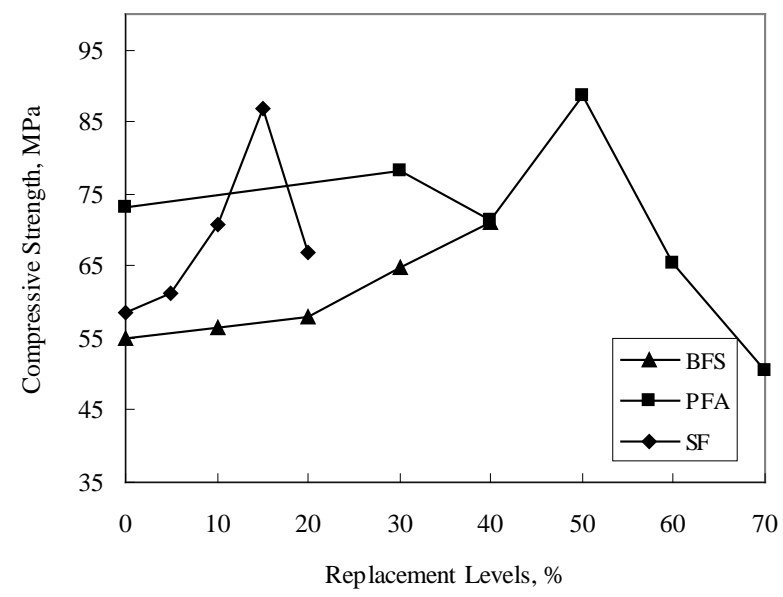

Figure (1): The Effect of the Investigated Materials on the Mortar Compressive Strength at 3-months age.

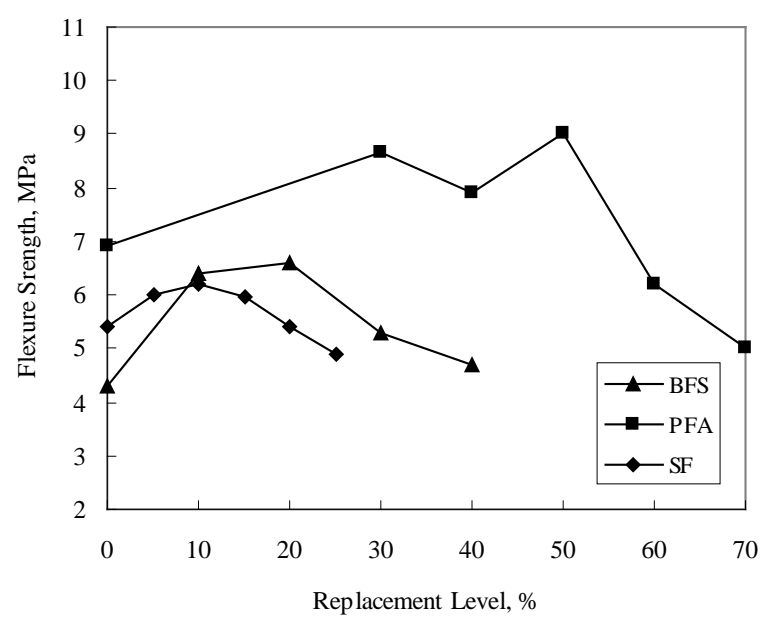

Figure (2): The Effect of the Investigated Materials on the Mortar Flexure Strength. 


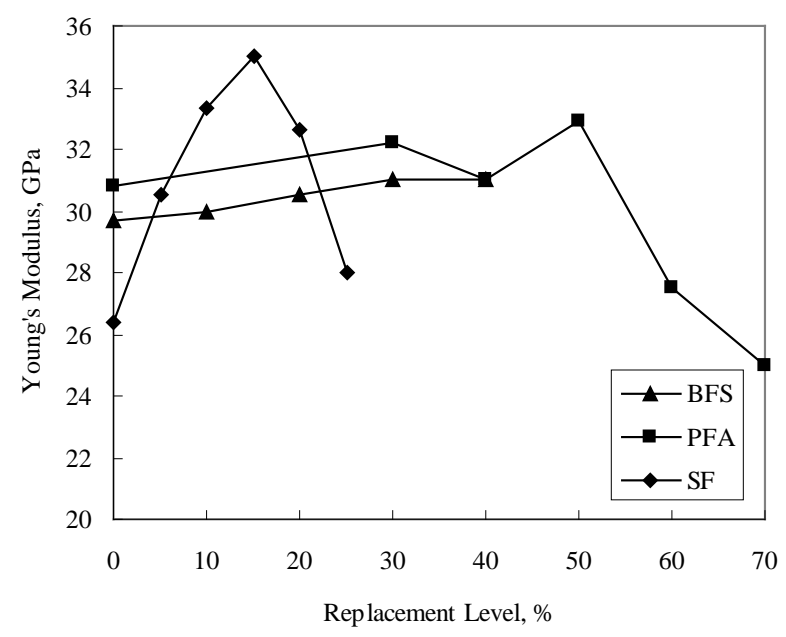

Figure (3): The Effect of the Investigated Materials on the Mortar Modulus of Elasticity.

\section{CONCLUSIONS}

The main focus of this study was re-using the industrial waste materials in producing high performance cement mortar possessing the most favorable engineering properties with economical cost required in developing countries and desired in developed countries as well.

Based on the results and observations of this experimental study, the following conclusions can be drawn as follows:

- The test results proved that the incorporation of BFS in a well designed mix can produce mortar not only cheap but also superior in many important characteristics to that of ordinary Portland cement.

- Mortar mixes with different PFA replacement levels showed higher workability than the control mix

- At 28-days age, replacing $50 \%$ of cement with PFA resulted in approximately equal compressive strength to that of the mix made of only Portland cement.

- The optimum limit of partial replacement of cement with SF was found to be $15 \%$ which exhibited the highest increase in strength.

- Irrespective of the type of replacement material, there was a good enhancement in compressive and flexure strengths at all replacement levels comparable to those of the control test specimens.

- The developed high performance mortar can be used in a variety of applications due to its high durability, chemical resistance, and long term strength.

- Significant environmental benefits can be also realized from this useful consumption of such industrial waste materials. 


\section{REFERENCES}

1. Al-Rabiah, A.R., and Bijen, J., "The Performance of Blast-Furnace Slag Concrete in a Hot Marine Environment- a case study," Proceedings of the 1st International Conference on R.C. Materials in Hot Climates, Al-Ain, United Arab Emirates, 24-27 April, 1994, PP. 599-613.

2. Korany, Y., "Application of Laminated Ferrocement in Repairing R.C. Slabs and Beams,” MSc.Eng. Thesis, The American University in Cairo, Egypt, 1996.

3. Ozyildirim, C., "Laboratory Investigation of Low-permeability Concretes Containing Slag and Silica Fume," ACI Materials Journal, V.91, No.2, March-April 1994, PP. 197-202.

4. Poponic, K., Kamenic, N., Tkolcic-Ciboci, B., and Soukup, V., "Technical experience in the Use of Industrial Waste for Building Materials Production and Environmental Impact," Proceedings of the International Conference on Environmental Implications of Construction With Waste Materials, Maastricht, The Netherlands, 10-14 November 1991, PP. 479-490.

5. Rankers, R. H., and Hohberg, I., "Leaching Tests for Concrete Containing Fly AshEvaluation and Mechanism," Proceedings of the International Conference on Environmental Implications of Construction With Waste Materials, Maastricht, The Netherlands, 10-14 November 1991, PP. 275-282.

6. Shaheen, Y.B.I. "Compressive Strength of Mortars Concrete," Proceedings of AlAzhar Second International Conference, Cairo, Egypt, 21-24 December, 1991, PP. 330-341.

7. Swamy, R.N., and Bouikni, A., "Some Engineering Properties of Slag Concrete as Influenced by Mix Proportioning and Curing," ACI Materials Journal, V.87, No.3, May-June 1990, PP. 210-220. 